\title{
DIVERSIFIED CLIMATE RESILIENT PECAN (CARYA ILLINOINENSIS (WANGENH.) K. KOCH) BASED SUSTAINABLE AGROFORESTRY IMPROVES LIVELIHOOD AND RETURNS IN INDIAN HIMALAYA
}

\author{
YAdAV, R. P. - Bisht, J. K. - Mondal, T. - MEena, V. S. - PANDEY, B. M. - Mishra, P. K. - \\ PATTANAYAK, A. - KANT, L. \\ ICAR-Vivekananda Parvatiya Krishi Anusandhan sansthan, Almora-263601, Uttarakhand, \\ India \\ ${ }^{*}$ Corresponding author \\ e-mail: rams34052@gmail.com
}

(Received . $3^{\text {rd }}$ Nov 2020; accepted $8^{\text {th }}$ Feb 2021)

\begin{abstract}
Mono-cropping systems are prone to increasing climate variability leading to biotic and abiotic pressure, which results in a risk of failure. Therefore, a diversified pecan-based agroforestry experiment was conducted (2010-2016) with an aim to enhance productivity, profitability and resilience over sole cropping (without pecan) in the rainfed ecosystem of the Indian Himalaya. It was hypothesized that integration of seasonal crops in the alleys of pecan trees will improve production, livelihood and returns due to diversified output. Four cropping systems, viz. FM-L, FM-W, S-L and S-W were evaluated under pecan and sole cropping. Between two situations, wheat equivalent grain yield (WEGY) and production efficiency (PE) were significantly higher in sole cropping (15.06 \& 16.3\%) as compared to under pecan. Among cropping systems WEGY was significantly higher in S-W ranging between 4.9 and $51.4 \%$ compared to other cropping systems. S-W system was also significantly more productive. In 2016 fruit, wood, litter fall and C stock were recorded as 1.11, 21.31, 8.44 and $46.50 \mathrm{t} \mathrm{ha}^{-1}$ for pecan, respectively. The grain productivity of crops was positively correlated with rainfall. The gross returns was threefold with pecan as compared to sole cropping (1345.9 $\left.\$ \mathrm{ha}^{-1}\right)$ concerning 2016. Irrespective of growing situations S-W (3629.2 \$ ha $\left.{ }^{-1}\right)$ cropping system provided maximum gross returns in year 2016. Hence, it is concluded that pecan-based agroforestry is more profitable in terms of economics, diversified output and ecological balance.
\end{abstract}

Keywords: agri-horticulture, cropping system, mono-cropping, productivity, wheat equivalent grain yield

\section{Introduction}

Globally, land and water are two of the most prominent resources for the growth and survival of humans (Schneider et al., 2011) and smart farming is need of the hour for social upliftment (Wolfert et al., 2017; Namatsheve et al., 2020). The land-use systems that strive escalating climatic vulnerabilities ensuring resilience are significant to enhance livelihood security and economic return with climate change mitigation and adaptation strategies (Yadav et al., 2016a; González-Esquivel et al., 2020; Orr et al., 2020). Agroforestry systems (AFS) which are sustainable in nature and provide diversified outputs, viz. fruits, food, timber, fuel wood, nuts and spices are pervasive globally (Adane et al., 2019). Food production for consumption and income generating potential of fruit tree based agroforestry attracts farming community than other trees to plant on the farm (Bellow et al., 2008a; Yadav et al., 2015a; Mondal et al., 2020). These AFS being a form of integrated land management (Leakey, 2010) increase resilience to climate change (Kalaugher et al., 2017; Yadav et al., 2017, 2019; Yasin et al., 2018), enhance efficiency of natural resources, and total factor productivity and mitigate food insecurity (Thangata et al., 2002). Fruit tree based agroforestry is more profitable due to uniform income 
distribution round the year, besides higher returns on inputs compared to mono-cropping (Yadav et al., 2018a). The extrinsic and intrinsic variables are taken into account to adopt the agroforestry innovations (Meijer et al., 2015) and for climate and food security tasks, agroforestry is one of the identified solution.

In Himalayan region, fruit based agroforestry is more appropriate livelihood option because of congenial climate for horticulture crops. In these fruit based AFS in spite of reduced yields of some annual crops compared to sole-cropping, it is economically more rewarding with higher gross returns (GR) and overall system productivity, i.e. fruit tree + annual crop. Complex interactions between system components and environment are responsible for varying increase and decrease in yields of annual crops under AFS (Bellow et al., 2008b). Performance of the fruit based agroforestry depends on crop (type, variety), trees type and climatic conditions of the area (Yadav et al., 2017, 2018b).

In the Himalayan region, most of the inhabitants depend on yields of crops, viz. finger millet, lentil, wheat, soybean besides other crops for subsistence. Fruit and vegetable crops are income earning cash crops besides domestic consumption. Fruit trees are popular among inhabitants of the region and found many on the farming lands. In entire Himalayan region, fruit based agroforestry is distributed in the form of scattered fruit trees on farming lands, including agricultural crops in orchards and home gardens (Yadav et al., 2016b, 2018c). In the area most common fruit trees are mango (Mangifera indica), citrus (Citrus spp.), pear (Pyrus communis), plum (Prunus domestica), apple (Malus domestica), apricot (Prunus armeniaca), peach (Prunus persica), walnut (Juglans regia), pecan (Carya illinoinensis) and aonla (Emblica officinalis) with other various species in smaller number (Yadav et al., 2016b; GoUK, 2020). The source of earnings for livelihood of the inhabitants is produce of these fruit trees besides livestock in the Himalayan region. Hence, fruit based agroforestry is an alternate land management option that can lead to improved income, production and stability for rainfed marginal lands which have low, unstable and uneconomic production.

The evaluation of fruit tree based agroforestry in Himalayan region will offer options to resource poor small farmers in similar hill agriculture ecosystems. The superiority of mixed cropping compared to sole cropping has been established (Bellow, 2004; Hossain et al., 2014) and land equivalent ratio (LER) >1.0 has been demonstrated (Li et al., 1999; Rahman et al., 2014). Fruit trees on farming land enjoys popularity and provides direct cash as well as indirect ecological benefits (Gaba et al., 2015; Yadav et al., 2019) which leads its acceptability and greater adoption (Parrotta et al., 2015). Fruit based agroforestry interests for sustainability in relation to disease and pest control (Simon et al., 2015), economic efficiency (Duru et al., 2015) and carbon neutral farming. Research on pecan with annual agricultural crops to optimize system yield is scarce. Considering the potential of fruit tree based agroforestry in the region, we evaluated different cropping systems (CS) for (i) their yields potential, (ii) characterization of productivity and (iii) gross returns with and without pecan (sole cropping).

\section{Materials and methods}

\section{Experimental site}

The study was conducted at the experimental farm, Hawalbagh $\left(29^{\circ} 36^{\prime} \mathrm{N} ; 79^{\circ} 40^{\prime} \mathrm{E}\right)$ of the ICAR-Vivekananda Parvatiya Krishi Anusandhan Sansthan, Almora located at an altitude of $1250 \mathrm{~m}$ above sea level. Annual mean temperature was $18.3{ }^{\circ} \mathrm{C}$ with mean maximum of $26.2^{\circ} \mathrm{C}$ and mean minimum of $10.5^{\circ} \mathrm{C}$ during the crop growth period of 
seven years (2010-2016). The mean annual rainfall was $973.7 \mathrm{~mm}$ with 81 mean number of rainy days majority $(70 \%)$ of which during June to September. Mean annual relative humidity, evaporation and sunshine hours were $70.7 \%, 2.4 \mathrm{~mm}^{\text {day }}{ }^{-1}$ and $6.5 \mathrm{~h} \mathrm{day}^{-1}$, respectively (Table 1).

Table 1. Mean meteorological parameters received during the study period (2010-2016)

\begin{tabular}{c|c|c|c|c|c|c|c}
\hline \multirow{2}{*}{ Year } & \multicolumn{2}{|c|}{ Temperature $\left.\mathbf{~}^{\mathbf{}} \mathbf{C}\right)$} & Rainfall & Number of & Evaporation \\
& Maximum & Minimum & $(\mathbf{m m})$ & rainy days & $\begin{array}{c}\text { Sunshine } \\
\left(\mathbf{m m} \text { day }^{-1}\right)\end{array}$ & $\begin{array}{c}\text { Mean relative } \\
\text { humidity (\%) }\end{array}$ \\
\hline 2010 & 26.8 & 10.8 & 1369.5 & 87 & 2.5 & 6.7 & 70.9 \\
2011 & 25.6 & 10.6 & 1088.0 & 90 & 2.2 & 6.4 & 71.6 \\
2012 & 26.2 & 10.0 & 849.4 & 87 & 2.5 & 6.4 & 67.8 \\
2013 & 26.1 & 10.8 & 1005.2 & 90 & 2.4 & 6.3 & 70.9 \\
2014 & 25.8 & 9.8 & 943.3 & 68 & 2.4 & 6.3 & 73.7 \\
2015 & 25.9 & 10.6 & 667.9 & 73 & 2.3 & 6.1 & 73.7 \\
2016 & 27.0 & 10.6 & 892.8 & 71 & 2.7 & 7.0 & 66.3 \\
\hline
\end{tabular}

\section{Experimental design and treatments}

In the present investigation four cropping systems: (i) finger millet $\{(\mathrm{FM})$ Eluesine coracana $\}$-lentil $\{(\mathrm{L})$ Lens esculentum $\}$, (ii) finger millet $\{(\mathrm{FM})$ Eluesine coracana $\}-$ wheat $\{(\mathrm{W})$ Triticum aestivum $\}$, (iii) soybean $\{(\mathrm{S})$ Glysine max $\}$-lentil $\{(\mathrm{L})$ (Lens esculentum $\}$ and (iv) soybean $\{(\mathrm{S})$ Glysine max) $\}$-wheat $\{(\mathrm{W})$ Triticum aestivum $\}$ were evaluated. Soybean and finger millet were grown in kharif season (June-September) and wheat and lentil were grown in rabi season (October-May). The pecan plantation was of 22 years old and planted at a spacing of $6 \mathrm{~m} \times 6 \mathrm{~m}$ with a density of 277 trees ha ${ }^{-1}$. These cropping systems were examined in two growing situation (GS) (i) under pecan and (ii) sole cropping (without pecan) in rainfed (irrigation was not provided) ecosystem. The experiment was laid out in Factorial Randomized Block Design (FRBD) with three replications for each treatment.

\section{Crop management}

The experimentation period for this study was of seven years from 2010 to 2016 . The crops, viz. soybean (VL Soya 63), finger millet (VL Mandua 324), wheat (VL Gehun 804 ) and lentil (VL Masoor 126) were grown with recommended dose of NPK (20:80:40; 40:20:20; 60:40:20 and 20:60:40, respectively) in rainfed condition. Urea, single super phosphate (SSP) and muriate of potash (MOP) was used to apply mineral N, P and K fertilization, respectively. The NPK was applied as basal dose in soybean and lentil, however, in wheat and finger millet nitrogen was applied in two equal splits at the time of field preparation, and after four weeks of sowing (Table 2). The gross plot size was $21.6 \mathrm{~m}^{2}(5.4 \mathrm{~m} \times 4.0 \mathrm{~m})$.

\section{Cropping system productivity}

The grain and straw/stover yield $\left(\mathrm{t} \mathrm{ha}^{-1}\right)$ for the annual agricultural crops and growth parameters $\{$ girth $(\mathrm{cm})$, height $(\mathrm{cm})\}$, yield $\left\{\right.$ fruit $\left(\mathrm{t} \mathrm{ha}^{-1}\right)$ and pruned material $\left.\left(\mathrm{t} \mathrm{ha}^{-1}\right)\right\}$ and accumulation of biomass $\left(\mathrm{t} \mathrm{ha}^{-1}\right)$, biomass $\mathrm{C}\left(\mathrm{t} \mathrm{ha}^{-1}\right)$ and litter fall $\left(\mathrm{t} \mathrm{ha}^{-1}\right)$ were recorded for the pecan. Wheat equivalent grain yield (WEGY) calculated by multiplying the grain 
yields of crops with their respective minimum support price (MSP), the value obtained so were divided with MSP of wheat. The PE was measured by dividing individual crop yield to number of days taken to harvest.

Table 2. Details of experiment and agronomic management during 2010-2016

\begin{tabular}{|c|c|c|c|c|}
\hline Experimentation period & \multicolumn{4}{|c|}{2010 to 2016 (Seven years) } \\
\hline Growing situation (GS) & \multicolumn{2}{|c|}{ Under pecan (Carya illinoinensis) } & \multicolumn{2}{|c|}{ Sole cropping } \\
\hline Cropping systems (CS) & \multicolumn{2}{|c|}{ Kharif } & \multicolumn{2}{|c|}{ Rabi } \\
\hline (i) & \multicolumn{2}{|c|}{ Finger millet (Eluesine coracana) } & \multicolumn{2}{|c|}{ Lentil (Lens esculentum) } \\
\hline (ii) & \multicolumn{2}{|c|}{ Finger millet } & \multicolumn{2}{|c|}{ Wheat (Triticum aestivum) } \\
\hline (iii) & \multicolumn{2}{|c|}{ Soybean (Glysine max) } & \multicolumn{2}{|c|}{ Lentil } \\
\hline (iv) & \multicolumn{2}{|c|}{ Soybean } & \multicolumn{2}{|c|}{ Wheat } \\
\hline Crops & Finger millet (FM) & Lentil (L) & Wheat (W) & Soybean $(\mathrm{S})$ \\
\hline Crop varieties & VL Mandua 324 & VL Masoor 126 & VL Gehun 804 & VL Soya 63 \\
\hline Seed rate $\left(\mathrm{kg} \mathrm{ha}^{-1}\right)$ & 10 & 35 & 100 & 75 \\
\hline Row distance $(\mathrm{cm})$ & 25 & 25 & 23 & 45 \\
\hline Sowing time & June & October & October & June \\
\hline $\begin{array}{c}\text { Fertilizer applied } \\
\left(\mathrm{N}-\mathrm{P}_{2} \mathrm{O}_{5}-\mathrm{K}_{2} \mathrm{O} \mathrm{kg} \mathrm{ha}^{-1}\right)\end{array}$ & $40: 20: 20$ & $20: 60: 40$ & $60: 40: 20$ & $20: 80: 40$ \\
\hline Maturity time (days) & $105-135$ & 168 & $164-178$ & 121 \\
\hline Harvesting time & October & April/May & April/May & October \\
\hline Experimental design & \multicolumn{4}{|c|}{ Factorial randomized block design } \\
\hline Replication & \multicolumn{4}{|c|}{03} \\
\hline
\end{tabular}

\section{Gross returns}

The grain and straw/stover yield of crops (soybean, finger millet, wheat and lentil) and pecan (fruit and fuel wood) were converted in monetary terms; resultant total returns were considered as gross returns. The gross return was converted into $\$$ based on the prevailing exchange rate of INR (Indian rupees) 75.9 for each $\$$.

\section{Statistical analysis}

Statistical analysis suggested by Gomez and Gomez (1984) was used to analyze the data in factorial randomized block design. JMP version 9.0.1 was used to measure analysis of variance. Means of growing situation, cropping systems and interaction, if any were compared at the $5 \%$ level of significance $(\mathrm{p}<0.05)$ using least significant difference (LSD).

\section{Results and discussions}

\section{Cropping system yield}

The results depicted in Table 3 revealed that among growing situation significantly higher $(15 \%)$ annual grain yield was obtained in sole cropping $\left(3.67 \mathrm{t} \mathrm{ha}^{-1}\right)$ compared to under pecan (3.19 $\left.\mathrm{t} \mathrm{ha}^{-1}\right)$. Likewise, during kharif and rabi higher (21.5 and 7.7\%) grain 
yield was recorded in sole cropping than under pecan (1.63 and $\left.1.56 \mathrm{t} \mathrm{ha}^{-1}\right)$, respectively. Among different cropping systems significantly 16.4, 47.2 and $73.9 \%$ higher annual grain yield was recorded from S-W system compared to FM-W, S-L and FM-L cropping systems, respectively. Similarly, ranging from 27.7 to $29.3 \%$ and 7.7 to $152 \%$ higher grain yield was obtained during kharif and rabi from $\mathrm{S}-\mathrm{W}$ system compared to remaining systems, respectively except for S-L system during kharif.

Table 3. Mean (2010-2016) grain yield under growing situation and different cropping systems

\begin{tabular}{|c|c|c|c|}
\hline \multirow[b]{2}{*}{ Treatments } & \multicolumn{3}{|c|}{ Mean grain yield $\left(\mathrm{t} \mathrm{ha}^{-1}\right)$} \\
\hline & $\begin{array}{c}\text { Kharif } \\
\text { (finger millet/soybean) }\end{array}$ & $\begin{array}{c}\text { Rabi } \\
\text { (lentil/ wheat) }\end{array}$ & Total (kharif $+r a b i)$ \\
\hline \multicolumn{4}{|l|}{ A. Growing situation (GS) } \\
\hline (i) Under pecan & $1.63 \mathrm{~b}$ & $1.56 \mathrm{~b}$ & $3.19 \mathrm{~b}$ \\
\hline (ii) Sole cropping & $1.98 \mathrm{a}$ & $1.68 \mathrm{a}$ & $3.67 \mathrm{a}$ \\
\hline $\operatorname{LSD}(\mathrm{P}<0.05)$ & 0.10 & 0.11 & 0.18 \\
\hline \multicolumn{4}{|l|}{ B. Cropping system (CS) } \\
\hline (i) Finger millet-lentil & $1.59 \mathrm{~b}$ & $0.94 \mathrm{c}$ & $2.53 \mathrm{~d}$ \\
\hline (ii) Finger millet-wheat & $1.57 \mathrm{~b}$ & $2.20 \mathrm{~b}$ & $3.78 \mathrm{~b}$ \\
\hline (iii) Soybean-lentil & $2.03 \mathrm{a}$ & $0.96 \mathrm{c}$ & $2.99 \mathrm{c}$ \\
\hline (iv)Soybean-wheat & $2.03 \mathrm{a}$ & $2.37 \mathrm{a}$ & $4.40 \mathrm{a}$ \\
\hline $\operatorname{LSD}(\mathrm{P}<0.05)$ & 0.14 & 0.16 & 0.26 \\
\hline $\mathrm{GS} \times \mathrm{CS}(\mathrm{P}<0.05)$ & NS & NS & NS \\
\hline
\end{tabular}

Ghosh et al. (2016) and Panday et al. (2018) under rainfed situation in similar type of cropping systems confirmed almost similar results for wheat and soybean yields in Himalayan region. However, these studies were in sole cropping systems and present study was includes pecan in addition to wheat-soybean cropping. Qin et al. (2015) also reported similar findings for soybean yield under rainfed conditions. S-W cropping system recorded $4.93 \mathrm{t} \mathrm{ha}^{-1}$ mean grain yield in a long term (21 years old) experiment under irrigated situation (Choudhary et al., 2018) which was a little higher than present study in Himalaya. However, soybean grain yield $\left(2.0 \mathrm{t} \mathrm{ha}^{-1}\right)$ was almost similar but wheat grain yield $\left(2.93 \mathrm{t} \mathrm{ha}^{-1}\right)$ was higher than present study. The grain yield under pecan and sole cropping during kharif $\left(\mathrm{R}^{2}=0.63 \& 0.32\right)$, rabi $\left(\mathrm{R}^{2}=0.003 \& 0.069\right)$ and annual grain productivity $\left(\mathrm{R}^{2}=0.54 \& 0.25\right)$ showed positive relationship with annual rainfall (Fig. 1).

The presence of fruit trees significantly reduced the grain yield of crops under different cropping systems compared to sole crop. This reduction in grain yields may be due to competitive effect for water, nutrients and light besides shading of fruit trees (Yadav et al., 2014b, 2015b). In similar type of study Hossain et al. (2014) reported that under fruit (mango, guava and olive) based agroforestry fruit yield of tomato was significantly lower (10.26-23.47 $\mathrm{t} \mathrm{ha}^{-1}$ ) than in sole cropping (34.06 $\mathrm{t} \mathrm{ha}^{-1}$ ) condition in Bangladesh. The yields of fava bean and maize under fruit trees reduced up to $34 \%$ in Guatemala and it was correlated with competition for water, nutrients and light (Bellow, 2004). 

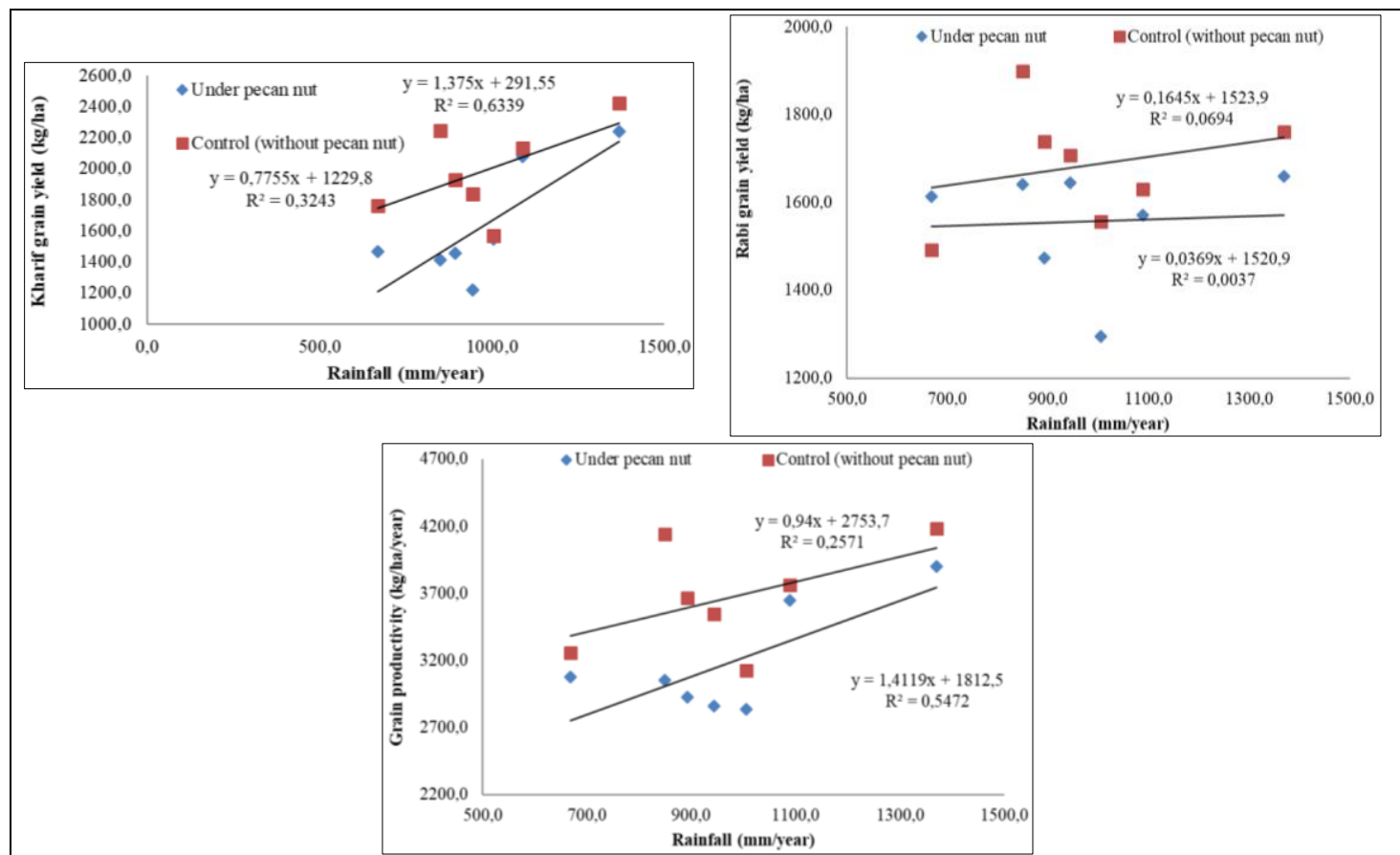

Figure 1. Linear relationship between kharif (rainy season), rabi (winter season) and annual grain yield (with pecan and sole cropping) with yearly rainfall

\section{Wheat equivalent grain yield (WEGY)}

The Fig. $2 a$ revealed that annual WEGY in sole cropping was significantly higher (15\%) compared to yield under pecan $\left(4.25 \mathrm{t} \mathrm{ha}^{-1}\right)$. The WEGY during kharif and rabi also followed the similar trend and was significant high (21.9 and 8.6\%) in sole cropping compared to under pecan (2.15 and $\left.2.09 \mathrm{t} \mathrm{ha}^{-1}\right)$, respectively (Fig. 2b). The interaction between growing season and growing situation was non-significant $(F i g .2 c)$. S-W system recorded 4.9, 46.2 and 51.4\% higher WEGY compared to S-L, FM-W and FM-L cropping systems, respectively (Fig. 2d). Likewise, the WEGY in S-W system was higher ranging from 96.9 to $99.4 \%$ and 7.7 to $15.6 \%$ during kharif and rabi, respectively than other cropping systems (Fig. 2e).

The interaction effect of year with growing situation and cropping systems (Fig. 2f) was significant $(\mathrm{P}<0.01)$ for WEGY. The WEGY of S-W system $\left(5.54 \mathrm{t} \mathrm{ha}^{-1}\right)$ was higher (4.9-51.4\%) than other cropping systems in rainfed situation. In Himalayan region, Panday et al. (2018) also reported lesser (4.71 $\left.\mathrm{t} \mathrm{ha}^{-1}\right)$ WEGY of S-W cropping system in a nine-year-old experiment under rainfed situation. Similar results also confirmed under rainfed situation by other researchers (Bhattacharyya et al., 2010; Qin et al., 2015). Whole model of actual versus predicted WEGY (Fig. $2 g$ ) was significant $\left(\mathrm{P}<0.01 ; \mathrm{R}^{2}=0.85\right)$.

\section{Production efficiency (PE)}

The mean PE was significantly higher in sole cropping (26.36 kg ha $\left.{ }^{-1} \mathrm{day}^{-1}\right)$ compared to under pecan $\left(22.67 \mathrm{~kg} \mathrm{ha}^{-1} \mathrm{day}^{-1}\right.$ ) irrespective of cropping systems (Table 4). The similar trend was also followed during kharif and rabi season and mean PE was significantly high (13.52 and $9.15 \mathrm{~kg} \mathrm{ha}^{-1} \mathrm{day}^{-1}$ ) in sole cropping as compared to under pecan (16.47 and $9.90 \mathrm{~kg} \mathrm{ha}^{-1} \mathrm{day}^{-1}$ ), respectively. Among cropping systems, S-W system recorded significantly higher $(17.9,36.2$ and $62.5 \%)$ grain PE in comparison to FM-W, 
S-L and FM-L systems, respectively. In the present study, the production efficiency was higher than the research findings of Panday et al. (2018) from S-W cropping system in Indian Himalayas.

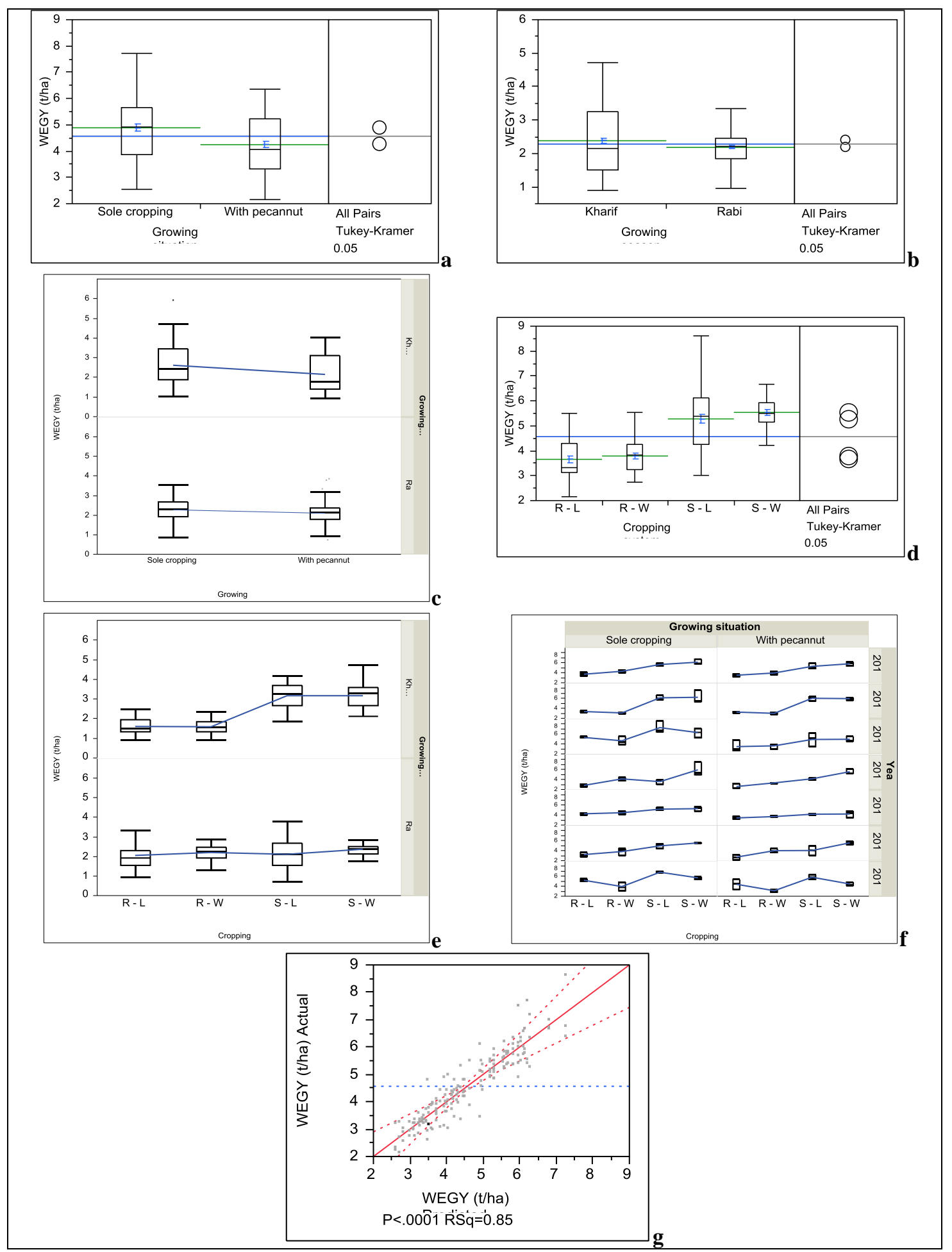

Figure 2. Effect of (a) growing situations (kharif + rabi) (b) growing season (c) growing situation $\times$ growing season $(d)$ cropping systems (kharif + rabi) (e) growing season $\times$ cropping systems $(f)$ year wise with growing situation and cropping system (kharif + rabi) $(g)$ whole model actual versus predicted wheat equivalent grain yield (WEGY) 
Table 4. Production efficiency (2010-2016) of crops under growing situation and different cropping systems

\begin{tabular}{|c|c|c|c|}
\hline \multirow[b]{2}{*}{ Treatments } & \multicolumn{3}{|c|}{ Production efficiency $\left(\mathrm{kg} \mathrm{ha}^{-1} \mathrm{day}^{-1}\right)$} \\
\hline & $\begin{array}{c}\text { Kharif } \\
\text { (Finger millet/soybean) }\end{array}$ & $\begin{array}{c}\text { Rabi } \\
\text { (lentil/wheat) }\end{array}$ & $\begin{array}{c}\text { Total } \\
\text { (kharif }+ \text { rabi) }\end{array}$ \\
\hline \multicolumn{4}{|l|}{ A. Growing situation (GS) } \\
\hline (i) Under pecan & $13.52 \mathrm{~b}$ & $9.15 \mathrm{~b}$ & $22.67 \mathrm{~b}$ \\
\hline (ii) Sole cropping & $16.47 \mathrm{a}$ & $9.90 \mathrm{a}$ & $26.36 \mathrm{a}$ \\
\hline $\operatorname{LSD}(\mathrm{P}<0.05)$ & 0.85 & 0.66 & 1.31 \\
\hline \multicolumn{4}{|l|}{ B. Cropping system (CS) } \\
\hline (i) Finger millet-lentil & $13.28 \mathrm{~b}$ & $5.59 \mathrm{c}$ & $18.87 \mathrm{~d}$ \\
\hline (ii) Finger millet-wheat & $13.13 \mathrm{~b}$ & $12.89 \mathrm{~b}$ & $26.02 \mathrm{~b}$ \\
\hline (iii) Soybean-lentil & $16.77 \mathrm{a}$ & $5.74 \mathrm{c}$ & $22.52 \mathrm{c}$ \\
\hline (iv) Soybean-wheat & $16.78 \mathrm{a}$ & $13.88 \mathrm{a}$ & $30.67 \mathrm{a}$ \\
\hline LSD $(\mathrm{P}<0.05)$ & 1.19 & 0.93 & 1.86 \\
\hline $\mathrm{GS} \times \mathrm{CS}(\mathrm{P}<0.05)$ & NS & NS & NS \\
\hline
\end{tabular}

Likewise, mean grain PE was recorded significantly higher in S-W system $\left(16.78 \mathrm{~kg} \mathrm{ha}^{-1}\right.$ day $\left.^{-1}\right)$ compared to FM-L $\left(13.28 \mathrm{~kg} \mathrm{ha}^{-1} \mathrm{day}^{-1}\right)$ and FM-W $\left(13.13 \mathrm{~kg} \mathrm{ha}^{-1} \mathrm{day}^{-1}\right)$ however it was at par in S-L cropping system $\left(16.77 \mathrm{~kg} \mathrm{ha}^{-1} \mathrm{day}^{-1}\right)$ in kharif season. During rabi season, significantly higher mean grain PE was also recorded in S-W system (13.88 kg ha ${ }^{-1}$ day $\left.^{-1}\right)$ compared to FM-W (12.89 kg ha day $\left.^{-1}\right)$, S-L $\left(5.74 \mathrm{~kg} \mathrm{ha}^{-1} \mathrm{day}^{-1}\right)$ and least under FM-L (5.59 $\mathrm{kg} \mathrm{ha}^{-1} \mathrm{day}^{-1}$ ) cropping systems during rabi season. Whole model for production efficiency actual versus predicted (Fig. 3) was significant $\left(\mathrm{P}<0.01 ; \mathrm{R}^{2}=0.87\right)$.

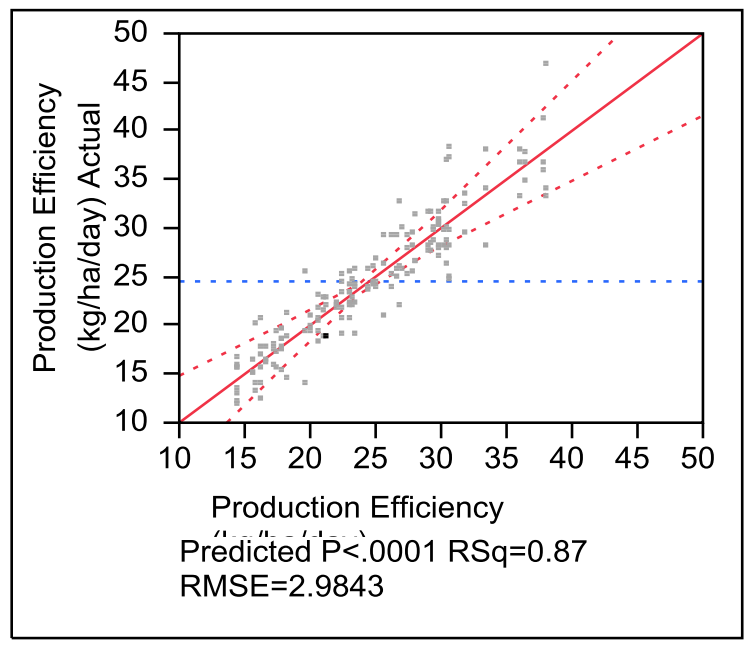

Figure 3. Whole model of production efficiency actual versus predicted

\section{Gross returns (GR)}

The gross returns was significantly two and four fold higher under pecan compared to sole cropping (\$933.9 and \$1345.9) during year 2010 and 2016, respectively (Table 5). The crops contribution in gross returns reduced from $43.6 \%$ during 2010 to $20.2 \%$ during 
2016, whereas contribution of pecan increased from $46.4 \%$ during 2010 to $79.8 \%$ during 2016. During $2010 \mathrm{~S}-\mathrm{W}$ system recorded 23.9, 25.1 and $29.1 \%$ more gross returns in comparisons to S-L, FM-W and FM-L cropping systems, respectively. Likewise, during 2016 among cropping systems, 2.52, 5.5 and 20.5\% higher gross returns was recorded from S-W system compared to S-L, FM-L and FM-W systems, respectively. The crops and pecan accounted for 52.7-63.7\% and 33.9-47.3\% gross returns during 2010. Similarly, during 2016 crops and pecan contributed ranging from 33.1 to $40.65 \%$ and 59.4 to $66.9 \%$ in gross returns. The contribution of crops decreased whereas pecan contribution increased in gross returns of different cropping systems during 2016 compared to during 2010.

Table 5. Gross returns (2010 and 2016) under growing situation and different cropping systems

\begin{tabular}{|c|c|c|c|c|c|c|}
\hline \multirow{3}{*}{ Treatments } & \multicolumn{6}{|c|}{ Gross returns (\$ ha $\left.{ }^{-1}\right)$} \\
\hline & \multicolumn{3}{|c|}{ Year 2010} & \multicolumn{3}{|c|}{ Year 2016} \\
\hline & Crop & Pecan nut & Total & Crop & Pecan nut & Total \\
\hline \multicolumn{7}{|c|}{ A. Growing situation (GS) } \\
\hline (i) Under pecan & $\begin{array}{l}874.3 \mathrm{~b} \\
(43.6 \%)\end{array}$ & $\begin{array}{c}1130.8 \\
(46.4 \%)\end{array}$ & $2005.2 \mathrm{a}$ & $\begin{array}{l}1104.0 \mathrm{~b} \\
(20.2 \%)\end{array}$ & $\begin{array}{c}4362.0 \\
(79.8 \%)\end{array}$ & $5466.0 \mathrm{a}$ \\
\hline (ii) Sole cropping & $933.9 \mathrm{a}$ & - & $933.9 \mathrm{~b}$ & $1345.9 \mathrm{a}$ & - & $1345.9 \mathrm{~b}$ \\
\hline $\operatorname{LSD}(\mathrm{P}<0.05)$ & 56.8 & - & 104.5 & 105.0 & - & 183.7 \\
\hline \multicolumn{7}{|c|}{ B. Cropping system (CS) } \\
\hline $\begin{array}{l}\text { (i) Finger millet- } \\
\text { lentil }\end{array}$ & $\begin{array}{l}710.3 \mathrm{c} \\
(52.7 \%)\end{array}$ & $\begin{array}{c}636.5 \\
(47.3 \%)\end{array}$ & $1346.8 \mathrm{~b}$ & $\begin{array}{l}1137.5 \mathrm{~b} \\
(33.1 \%)\end{array}$ & $\begin{array}{l}2304.1 \mathrm{a} \\
(66.9 \%)\end{array}$ & $3441.7 \mathrm{a}$ \\
\hline $\begin{array}{l}\text { (ii) Finger millet- } \\
\text { wheat }\end{array}$ & $\begin{array}{l}918.2 \mathrm{~b} \\
(66.1 \%)\end{array}$ & $\begin{array}{c}471.4 \\
(33.9 \%)\end{array}$ & $1389.6 \mathrm{~b}$ & $\begin{array}{l}1007.8 \mathrm{~b} \\
(33.4 \%)\end{array}$ & $\begin{array}{l}2005.2 \mathrm{~b} \\
(66.5 \%)\end{array}$ & $3013.1 \mathrm{~b}$ \\
\hline (iii) Soybean-lentil & $\begin{array}{l}880.4 \mathrm{~b} \\
(62.7 \%)\end{array}$ & $\begin{array}{c}522.6 \\
(37.3 \%)\end{array}$ & $1403.0 \mathrm{~b}$ & $\begin{array}{l}1435.5 \mathrm{a} \\
(40.6 \%)\end{array}$ & $\begin{array}{l}2104.4 \mathrm{a} \\
(59.4 \%)\end{array}$ & $3539.9 \mathrm{a}$ \\
\hline (iv) Soybean-wheat & $\begin{array}{l}1107.4 \mathrm{a} \\
(63.7 \%)\end{array}$ & $\begin{array}{c}631.2 \\
(36.3 \%)\end{array}$ & $1738.7 \mathrm{a}$ & $\begin{array}{l}1318.9 \mathrm{a} \\
(36.3 \%)\end{array}$ & $\begin{array}{l}2310.2 \mathrm{a} \\
(63.7 \%)\end{array}$ & $3629.2 \mathrm{a}$ \\
\hline $\operatorname{LSD}(\mathrm{P}<0.05)$ & 80.4 & NS & 147.8 & 148.5 & 210.1 & 259.8 \\
\hline $\mathrm{GS} \times \mathrm{CS}(\mathrm{P}<0.05)$ & NS & NS & NS & NS & NS & NS \\
\hline
\end{tabular}

In Himalayan region, the research findings of Panday et al. (2018) confirmed the gross return (\$1092.2) from soybean-wheat system, which was lower to this study under rainfed situation. Similar type of result was confirmed for gross returns from maize-wheat cropping system under rainfed situation (Sharma et al., 2017). The gross returns of year 2010 and 2016 (Fig. 4) with growing situation and cropping system was significant $(\mathrm{P}<0.01)$.

The findings of the present study reveals that fruit based AFS have provided more gross returns compared to cropping without fruit trees. The net returns and benefit was almost double in mango + tomato and guava + tomato agroforestry compared to pure cropping of tomato in Bangladesh (Hossain et al., 2014). In South Ethiopia, Anshiso et al. (2017) also reported that the net present value of fruit-tree based agroforestry practice was two, five and four times higher than ginger, sequential mono-cropping of maize with sweet potato and taro with teff. Similar findings that AFS are financially more beneficial and productive than pure cropping (without tree component) have been reported by Ajayi et al. (2009) in Zambia, Getahun (2012) and Adane et al. (2019) in Ethiopia and Yadav 
et al. (2018a,b) in Indian Himalaya. The whole model of gross returns actual versus predicted (Fig. 5) was significant $\left(\mathrm{P}<0.01 ; \mathrm{R}^{2}=0.99\right)$.

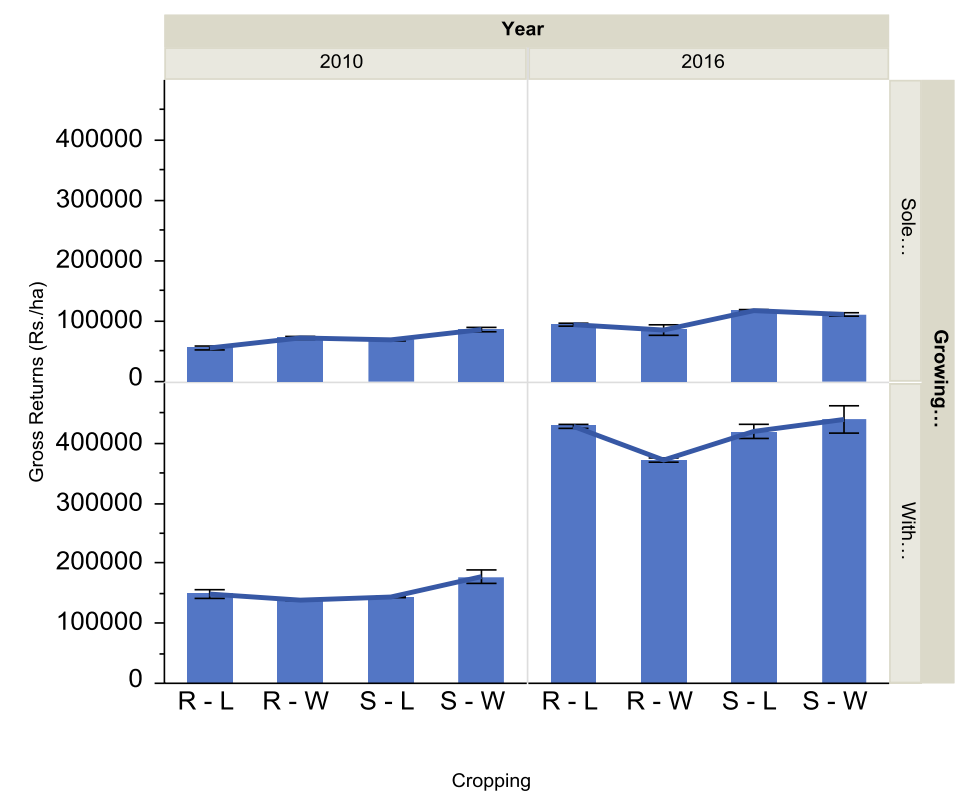

Figure 4. Gross returns according to cropping system, growing situation and year wise

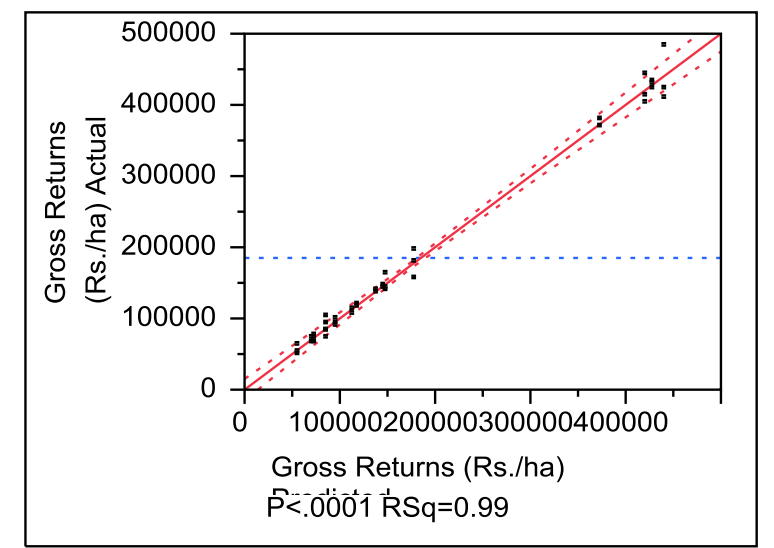

Figure 5. Whole model of gross returns actual versus predicted

\section{Growth and yield of pecan}

The girth and height of pecan were increased from $56.94 \mathrm{~cm}$ and $9.15 \mathrm{~m}$ per plant in the year of 2010 (when the experiment was initiated) to $76.18 \mathrm{~cm}$ and $10.69 \mathrm{~m}$ per plant, respectively at the end of the experimentation in the year of 2016 (Fig. 6). Likewise, wood and fruit yields were 11.70 and $0.81 \mathrm{t} \mathrm{ha}^{-1}$ in 2010 and 21.31 and $1.11 \mathrm{t} \mathrm{ha}^{-1}$, respectively in the year of 2016. Crown spread was increased from $6.13 \mathrm{~m} / \mathrm{plant}$ in 2010 to $7.29 \mathrm{~m} /$ plant in 2016. Similarly, in the year 2010 the litter fall and biomass C were 1.96 and $23.88 \mathrm{t} /$ ha which increased to 8.44 and $46.50 \mathrm{t} \mathrm{ha}^{-1}$, respectively in the year of 2016 .

The linear increase in the growth parameters (girth and height) of pecan during experimentation period (2010-2016) helped to improve yields (wood and fruits) and 
accumulation of more litter, biomass and biomass $\mathrm{C}$ stock. This supported to enhance profitability in economic terms besides ecological benefits. Stem diameter at breast height $(\mathrm{DBH})$ of pecan increased linearly with time, hulled nut production ranged from 0.05 to $1.60 \mathrm{t} \mathrm{ha}^{-1}$ with 35 to 74 trees $\mathrm{ha}^{-1}$ in a stands of 72 years of age (average) and production of woody material improved the profitability of pecan-based system (Aries et al., 2006). In this present study, the gross returns are higher in pecan-based cropping system. Besides pecan, also help in improving soil properties via litter fall and meet the subsistence requirements of the farming community.

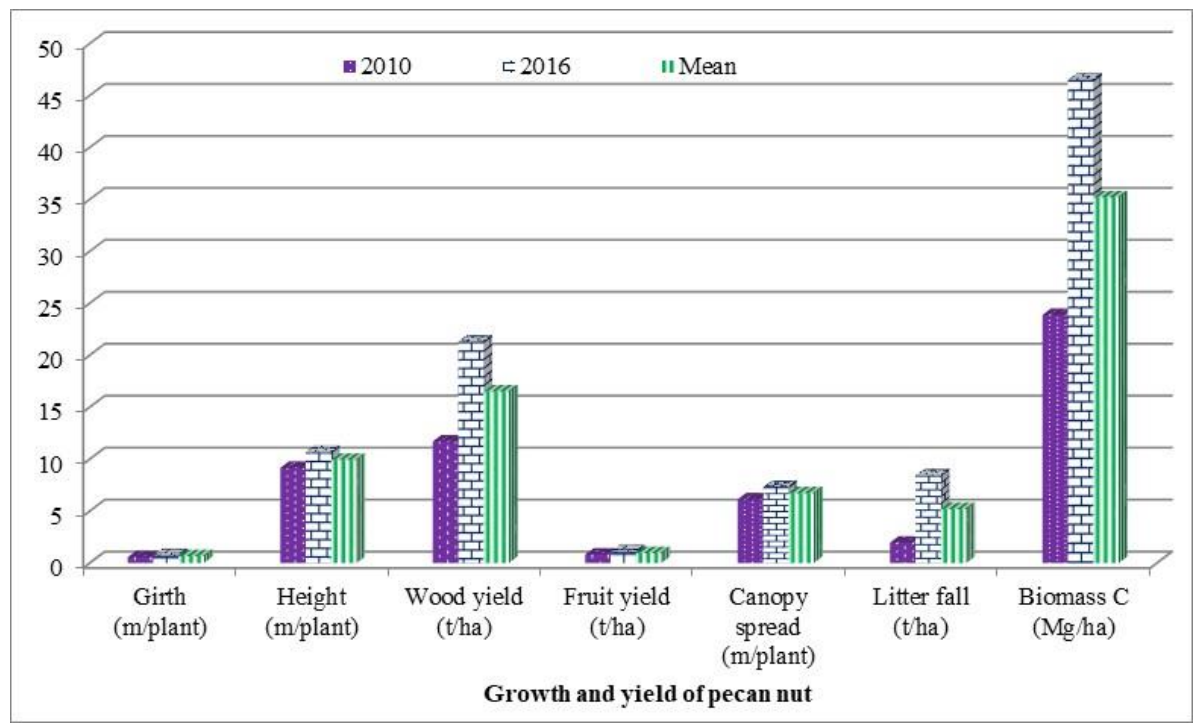

Figure 6. Girth, height, wood yield, fruit yield, canopy spread, litter fall and biomass C (2010 and 2016) of pecan in rainfed pecan-based agroforestry system

\section{Conclusions}

The results from this study indicated that sole cropping situation is more productive as compared to under pecan in terms of crop yield, wheat equivalent yield and production efficiency. Higher crop yield, wheat equivalent yield and production efficiency was obtained from S-W cropping system, hence, it is a suitable cropping system Indian Himalaya. However, from economic point of view the cropping under pecan was more remunerative to the farmers of rainfed situation. S-W system was provided highest gross returns followed by S-L, FM-L and FM-W cropping systems. Diversified output the farmers obtain from agroforestry such as food, fruit, pruned material as firewood, nuts etc. ensure livelihood security at inaccessible hill location. Litter fall from fruit trees enhance soil inherent capacity through decomposition that improves the soil structure and fertility. The fruit tree based agroforestry increases livelihood security, productivity and profitability of farmers. Besides pecan being a fruit tree, improve climate resilience via capturing atmospheric $\mathrm{CO}_{2}$ in its tissues and store in the form of $\mathrm{C}$ for the long term. However, attempts on nutrient returns via litter fall and fruit production predictions required strengthening investment for spreading pecan plantation. Hence, pecan-based agroforestry is economically more viable and climate resilient option for the rainfed areas of the hill farming community in Himalayas. 
Acknowledgements. Authors acknowledge the support received from Director of ICAR-Vivekananda Parvatiya Krishi Anusandhan Sansthan, Almora for providing necessary facilities and field staff for carrying out field activity during the course of investigation.

\section{REFERENCES}

[1] Adane, F., Legesse, A., Weldeamanuel, T., Belay, T. (2019): The contribution of a fruit tree-based agroforestry system for household income to smallholder farmers in Dale District, Sidama Zone, Southern Ethiopia. - Advances in Plants and Agriculture Research 9(1): 78-84.

[2] Ajayi, O. C., Akinnifesi, F. K., Sileshi, G., Kanjipite, W. (2009): Labour inputs and financial profitability of conventional and agroforestry-based soil fertility management practices in Zambia. - Agrekon 48(3): 276-292.

[3] Anshiso, A., Woldeamanuel, T., Asfaw, Z. (2017): Financial analysis of fruit tree based agroforestry practice in Hadero Tunto Zuria Woreda, Kembata Tembaro Zone, South Ethiopia. - Research Journal of Finance and Accounting 8(3): 72-80.

[4] Aries, A., Reid, W., Brauer, D. (2006): Production and economics of native pecan silvopastures in central United States. - Agroforestry Systems 66(3): 205-215.

[5] Bellow, J. G. (2004): Fruit-tree-based agroforestry in the western highlands of Guatemala. - Dissertation, University of Florida, Gainesville, FL, USA.

[6] Bellow, J. G., Hudson, R. F., Nair, P. K. R. (2008a): Adoption potential of fruit-tree-based agroforestry on small farms in the subtropical highlands. - Agroforestry Systems 73: 2336.

[7] Bellow, J. G., Nair, P. K. R., Martin, T. A. (2008b): Tree-crop interactions in fruit tree based agroforestry systems in the western highlands of Guatemala: component yields and system performance. - In: Jose, S., Gordon, A. M. (eds.) Towards Agroforestry Design. Advances in Agroforstry, Vol 4, Springer, Dordrecht.

[8] Bhattacharyya, R., Pandey, A. K., Gopinath, K. A., Mina, B. L., Bisht, J. K., Bhatt, J. C. (2016): Fertilization and crop residue addition impacts on yield sustainability under a rainfed maize-wheat system in the Himalayas. - Proceedings of National Academy of Sciences India, Section B Biological Sciences 86: 21-32.

[9] Choudhary, M., Panday, S. C., Meena, V. S., Singh, S., Yadav, R. P., Mahanta, D., Mondal, T., Mishra, P. K., Bisht, J. K., Pattanayak, A. (2018): Long-term effects of organic manure and inorganic fertilization on sustainability and chemical soil quality indicators of soybeanwheat cropping system in the Indian mid-Himalayas. - Agriculture, Ecosystems and Environment 257: 38-46.

[10] Duru, M., Therond, O., Fares, M. (2015): Designing agroecological transitions: a review. - Agronomy for Sustainable Development 35: 1237-1257.

[11] Gaba, S., Lescourret, F., Boudsocq, S., Enjalbert, J., Hinsinger, P., Journet, E., Navas, M., Wery, J., Louarn, G., Malezieux, E., Pelzer, E., Prudent, M., Ozier-Lafontaine, H. (2015): Multiple cropping systems as drivers for providing multiple ecosystem services: from concepts to design. - Agronomy for Sustainable Development 35: 607-623.

[12] Getahun, K. M. (2012): Economic analysis and determinants of fruit tree based agroforestry system in Wondo district, Ethiopia: comparative analysis with monocropping systems. M.Sc. thesis, Wondo Genet College of Forestry and Natural Resources, Hawassa University, Ethiopia.

[13] Ghosh, B. N., Meena, V. S., Alam, N. M., Dogra, P., Bhattacharyya, R., Sharma, N. K., Mishra, P. K. (2016): Impact of conservation practices on soil aggregation and the carbon management index after seven years of maize-wheat cropping system in the Indian Himalayas. - Agriculture Ecosystem Environment 216: 247-257.

[14] Gomez, K. A., Gomez, A. A. (1984): Statistical Procedures for Agricultural Research, $2^{\text {nd }}$ edition. - ISBN: 978-0-471-87092-0, 704p. 
[15] González-Esquivel, C. E., Camacho-Moreno, E., Larrondo-Posadas, L., Sum-Rojas, C., León-Cifuentes, W. E., Vital-Peralta, E., Astier, M., López-Ridaura, S. (2020): Sustainability of agroecological interventions in small scale farming systems in the Western Highlands of Guatemala. - International Journal of Agricultural Sustainability 18(4): 285-299.

[16] Government of Uttarakhand. (2020): State Profile. - Department of Horticulture, Government of Uttarakhand, India. Accessed on January 21, 2020.

[17] Hossain, J., Ahamed, T., Hasnat, M. Z., Karim, D. (2014): Screening of tomato varieties for fruit tree based agroforestry system. - International Journal of Agricultural Research, Innovation and Technology 4(2): 61-69.

[18] Kalaugher, E., Beukes, P., Bornman, J. F., Clark, A., Campbell, D. I. (2017): Modelling farm-level adaptation of temperate, pasture-based dairy farms to climate change. Agricultural system 153: 53-68.

[19] Leakey, R. R. B. (2010): Should we be growing more trees on farms to enhance the sustainability of agriculture and increase resilience to climate change. - Special Report, ISTF News, USA.

[20] Li, L., Yang, S., Li, X., Zhang, F., Christie, P., Li, L., Yang, S. C., Li, X. L., Zhang, F. S. (1999): Interspecific complementary and competitive interactions between intercropped maize and faba bean. - Plant and Soil 212: 105-114.

[21] Meijer, S. S., Catacutan, D., Ajayi, O. C., Sileshi, G. W., Nieuwenhuis, M. (2015): The role of knowledge, attitudes and perceptions in the uptake of agricultural and agroforestry innovations among smallholder farmers in sub-Saharan Africa. - International Journal of Agricultural Sustainability 13(1): 40-54.

[22] Mondal, T., Yadav, R. P., Meena, V. S., Choudhary, M., Nath, S., Bisht, J. K., Mishra, P. K., Arya, S. K., Pattanayak, A. (2020): Biomass yield and nutrient content of dual purpose wheat in the fruit based cropping system in the North-Western mid-Himalaya ecosystem, India. - Field Crops Research 247:107700. doi: 10.1016/j.fcr.2019.107700.

[23] Namatsheve, T., Cardinael, R., Corbeels, M., Chikowo, R. (2020): Productivity and biological $\mathrm{N}_{2}$-fixation in cereal-cowpea intercropping systems in sub-Saharan Africa. A review. - Agronomy for Sustainable Development 40: 30. https://doi.org/10.1007/s13593-020-00629-0.

[24] Orr, A., Tiba, Z., Congrave, J., Porázik, P., Dejen, A., Hassen, S. (2020): Smallholder commercialization and climate change: a simulation game for teff in South Wollo, Ethiopia. - International Journal of Agricultural Sustainability. doi: 10.1080/14735903.2020.1792735.

[25] Panday, S. C., Choudhary, M., Singh, S., Meena, V. S., Mahanta, D., Yadav, R. P., Pattanayak, A., Bisht, J. K. (2018): Increasing farmer's income and water use efficiency as affected by long-term fertilization under a rainfed and supplementary irrigation in a soybean-wheat cropping system of Indian mid-Himalaya. - Field Crops Research 219: 214221.

[26] Parrotta, J. A., de Pryck, J. D., Obiri, B. D., Padoch, C., Powell, B., Sandbrook, C., Agarwal, B., Ickowitz, A., Jeary, K., Serban, A., Sunderland, T. C. H., Tran, N. T. (2015): The historical, environmental and socio-economic context of forests and tree-based systems for food security and nutrition. - In: Forests, Trees and Landscapes for Food Security and Nutrition. A Global Assessment Report. https://www.researchgate.net/publication/276950253

[27] Qin, W., Wang, D., Guo, X., Yang, T., Oenema, O. (2015): Productivity and sustainability of rainfed wheat-soybean system in the North China Plain: results from a long-term experiment and crop modelling. - Scientific Reports 5: 17514.

[28] Rahman, G. M. M., Wadud, M. A., Shahjahan, M., Jewel, K. N. A. (2014): Fruit tree based agroforestry practices in char land farming system. - Journal of Agroforestry and Environment 8(1): 1-6. 
[29] Schneider, U. A., Havlik, P., Schmid, E., Valin, H., Mosnier, A., Obersteiner, A., Bottcher, H., Skalsky, R., Balkovik, J., Sauer, T., Fritz, Z. (2011): Impacts of population growth, economic development, and technical change on global food production and consumption. - Agricultural System 104: 204-215.

[30] Sharma, N. K., Singh, R. J., Mandal, D., Kumar, A., Alam, N. M., Keesstra, S. (2017): Increasing farmer's income and reducing soil erosion using intercropping in rainfed maizewheat rotation of Himalaya, India. - Agriculture Ecosystem and Environment 247: 43-53.

[31] Simon, S., Lesueur-Jannoyer, M., Plénet, D., Lauri, P., le Bellec, F. (2015): Design of innovative orchards: proposal of an adapted conceptual framework. $-5^{\text {th }}$ Intern Symp for Farm Syst Design. 7-10 September 2015, Montpellier, France.

[32] Thangata, P. H., Hildebrand, P. E., Gladwin, C. H. (2002): Modeling agroforestry adoption and household decision making in Malawi. - African studies quarterly 6(1): 271-293.

[33] Wolfert, S., Ge, L., Verdouw, C., Bogaardt, M. (2017): Big Data in Smart Farming-A review. - Agricultural System 153: 69-80.

[34] Yadav, R. P., Bana, O. P. S., Kaushal, R., Rajput, P. R. (2014): Effect of pruning in jatropha (Jatropha curcas linn.) and fertility levels in wheat on performance of agrisilviculture system in Tarai region of Uttarakhand. - Indian J. of Agroforestry 16(2): 68-72.

[35] Yadav, R. P., Bisht, J. K., Pandey, B. M. (2015a): Aboveground biomass and carbon stock of fruit tree based land use systems in Indian Himalaya. - The Ecoscan 9(3-4): 779-783.

[36] Yadav, R. P., Bana, O. P. S., Kaushal, R., Rajput, P. R. (2015b): Growth analysis and yield of wheat in agrisilviculture system in Tarai region of north-west India. - Indian Forester 141(3): 313-318.

[37] Yadav, R. P., Bisht, J. K., Pandey, B. M., Kumar, A., Pattanayak, A. (2016a): Cutting management versus biomass and carbon stock of oak under high density plantation in Central Himalaya, India. - Applied Ecology \& Environmental Research 14(3): 207-214.

[38] Yadav, R. P., Gupta, B., Bhutia, P. L., Bisht, J. K. (2016b): Socioeconomics and sources of livelihood security in Central Himalaya, India: a case study. - International Journal of Sustainable Development \& World Ecology 24(6): 545-553.

[39] Yadav, R. P., Bisht, J. K., Bhatt, J. C. (2017): Biomass, carbon stock under different production systems in the mid hills of Indian Himalaya. - Tropical Ecology 58(1): 15-21.

[40] Yadav, R. P., Gupta, B., Bhutia, P. L., Bisht, J. K. (2018a): Sustainable agroforestry systems for livelihood security and their economic appraisal in Indian Himalayas. Economic Affairs 63(3): 01-07.

[41] Yadav, R. P., Bisht, J. K., Mondal, T., Meena, V. S., Choudhary, M. (2018b): Peach based horti-pastoral system of forage production on marginal land in Indian Himalaya. - Indian Journal of Agroforestry 20(2): 63-67.

[42] Yadav, R. P., Gupta, B., Bhutia, P. L., Bisht, J. K., Pattanayak, A. (2018c): Sustainable agroforestry systems and their structural components as livelihood options along elevation gradient in central Himalaya. - Biological Agriculture \& Horticulture 35(2): 73-95.

[43] Yadav, R. P., Gupta, B., Bhutia, P. L., Bisht, J. K., Pattanayak, A., Meena, V. S., Choudhary, M., Tiwari, P. (2019): Biomass and carbon budgeting of sustainable agroforestry systems as ecosystem service in Indian Himalayas. - International Journal of Sustainable Development \& World Ecology 26(5): 460-470.

[44] Yasin, G., Nawaz, M. F., Siddiqui, M. T., Niazi, N. K. (2018): Biomass, carbon stocks and $\mathrm{CO} 2$ sequestration in three different aged irrigated Populus deltoides Bartr. Ex Marsh. bund planting agroforestry systems. - Applied Ecology and Environmental Research 16(5): 6239-6252. 


$$
-1323 \text { - }
$$

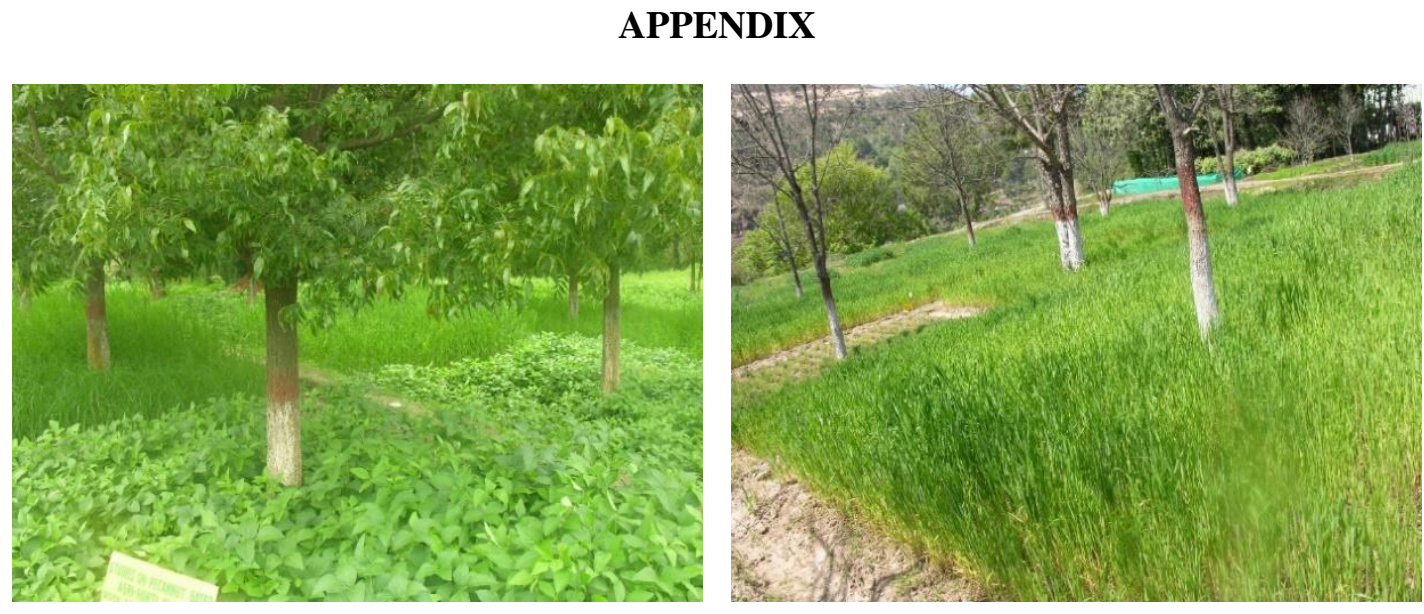

Appendix 1. Photo plate of experiments area during (a) kharif and (b) rabi season 